\title{
AWARENESS AND KNOWLEDGE OF PRO-, PRE- BIOTICS AND AB CULTURES AMONG YOGHURT BUYERS IN FOUR PRETORIA SUBURBS AND THE FACTORS DETERMINING THEIR YOGHURT BUYING DECISION
}

\author{
Irma Venter* \& Madelein Hanekom
}

\begin{abstract}
OPSOMMING
Voedselprodukte en voedingaanvullings wat probiotika bevat is in Suid-Afrika beskikbaar. " $n$ Pers debat het reeds hier oor beweerde en werklike probiotika produkinhoud geheers. Tans word wetgewing oor pro- en prebiotika aansprake vir voedselproduk etikette gefinaliseer.
\end{abstract}

Die doelwit met opname was om verbruikerbewustheid en kennis van pro-, prebiotika en $A B$ kulture vas te stel omdat hierdie faktore die ontwikkeling en aankope van voedselprodukte wat bioaktiewe bestanddele bevat ("funksionele voedsel") bevorder. "AB kulture" is ingesluit omdat dit reeds jare lank die teenwoordigheid van gesondheidgunstige bakterieë in Suid-Afrikaanse jogurt aandui. Die opname het ook die faktore nagegaan wat die verbruiker se jogurt aankoop keuse bepaal.

Die data is ingesamel met 'n getoetste vraelys wat grootliks uit veelkeuse vrae bestaan. Dit het onder meer vrae bevat oor die deelnemer se bewustheid van die bioaktiewe bestanddele; sy/haar jogurtinname en die aankoop faktore; die gebruik van 'n voedingaanvulling (omdat dit verband hou met ' $n$ gesonder lewenstyl) en demografiese inligting. Oop vrae is gebruik waar deelnemers moes beskryf wat elkeen van die bioaktiewe bestanddele beteken. Gepubliseerde definisies vir pro- en prebiotika is gebruik om sleutelwoorde in die antwoorde te identifiseer en daarvolgens te bepaal of die korrekte betekenis vir elk verskaf is.

Jogurt kopers is sistematies verkry deur elke derde koper in vier winkels geleë in voorstedelike gebiede van Pretoria te nader vir deelname. Jogurt kopers is gebruik omdat pro-en prebiotika ontwikkeling in die suiwelprodukte mark plaasvind. Omdat die aankope van funksionele voedsel meer in hoër sosioekonomiese groepe plaasvind, is winkels in gebiede wat dié mark bedien gebruik om deelnemers te verkry.

Drie honderd en elf van die 376 genooide verbruikers het vrywillig deelgeneem. Elf vraelyste is uitgesluit. Die 300 deelnemers was meerendeels vroulik $(65,7 \%), 18$ tot 39 jaar $(66,7 \%)$ en voedingaanvulling gebruikers $(63,3 \%)$. Veertien persent van die deelnemers in hierdie studie, en in 'n 2005 Markinor op- name, was bewus van die term "probiotika". Slegs $10,7 \%$ het ' $n$ beskrywing daarvan aangedui, waarvan $56,3 \%$ korrek was. Ongeveer $27 \%$ was bewus van $A B$ kulture en $16,3 \%$ het ' $n$ beskrywing daarvan aangedui, waarvan $49 \%$ korrek was. Slegs tien van die deelnemers was bewus van die term "prebiotika" en slegs ses het dit beskryf. Twee van dié deelnemers het dit korrek beskryf.

Deelnemers se geslag, hul ouderdomsgroepering, inname van jogurt en voedingaanvullings (of nie), het nie die bewustheid $(p>0,05)$ of korrekte beskrywing $(p>0,05)$ van die bioaktiewe bestanddele beïnvoed nie. Bewustheid van $A B$ kulture en bewustheid van prebiotika onderskeidelik het egter ' $n$ betekenisvolle verband $(p<0,001)$ getoon ten opsigte van die bewustheid van probiotika.

Onder die deelnemers wat jogurt geniet $(89 \%)$ het geur $(65,9 \%)$ en smaak $(62,2 \%)$ grootliks hul jogurt aankoop keuse bepaal. Tagtig persent van die deelnemers het aangedui dat hulle belangstel om meer van die onderwerp te weet.

Die belangsrikste gevolgtrekkings was dat die meeste jogurt kopers as hoofstroom verbruikers onbewus was van probiotika (en nog te meer prebiotika) en $A B$ kulture hoewel hulle aan die terme blootgestel was. Alhoewel daar ' $n$ bewustheid van probiotika en $A B$ kulture was, was kennis daarvan gebrekkig. Geslag, ouderdom en die inname van jogurt of voedingaanvullings (of nie) het nie die bewustheid of kennis van probiotika of $A B$ kulture beïnvloed nie. Tog het ' $n$ bewustheid van prebiotika en ' $n$ bewustheid van $A B$ kulture onderskeidelik ' $n$ verband getoon met die bewustheid van probiotika. Alhoewel die teenwoordigheid van gesondheidgunstige bakterieë nie die aankope besluit van jogurt bepaal het nie, was daar groot belangstelling onder die deelnemers om meer van pro- en prebiotika te weet.

- Ms I Venter*

Department of Agricultural and Food Sciences

Cape Peninsula University of Technology

E-mail:venteri@cput.ac.za

Tel.: +27214603428

Fax: +27214603854 


*Corresponding author
- Ms M Hanekom
Department of Agricultural and Food Sciences
Cape Peninsula University of Technology
ACKNOWLEDGMENTS: The food retail chain
store managers and customers for making the survey
possible and Ms K Kruger for the statistical analysis
of the data.

\section{INTRODUCTION}

Functional foods are an innovative new food product category (Mark-Herbert, 2004). "Functional foods" are broadly defined as "foods that provide more than simple nutrition; they supply additional physiological benefit to the consumer" (Jones, 2002) or more commonly "foods which promote health beyond providing basic nutrition"(Klaenhammer et al, 1998). Fermented milks and yoghurt containing probiotic bacteria are the best-known (Klaenhammer et al, 1998) and largest segment of the functional food market in many countries (Saarela et al, 2002).

Probiotic food products and dietary supplements are commercially available in South Africa (SA) (Theunissen \& Witthuhn, 2004; Theunissen et al, 2005). Regular internet users in an Internet survey conducted across 38 countries were asked what foods in a list of ten major food types that promote specific health benefits, they purchased. South African buyers were ranked the highest for six of the ten surveyed foods, despite SA considered an emerging market for functional foods. Yoghurt with Acidophilus cultures / probiotics was among the most frequently purchased $(44 \%)$ of the foods surveyed (ACNielsen, 2005). SA is furthermore finalising claims for pro- and prebiotics in its regulations relating to the labelling and advertising of foodstuffs (South Africa, Department of Health, 2007). Probiotics has also received intensive publicity in the popular press in SA and a probiotics manufacturer debate on viable organism levels claimed on product labels and the actual contents also spanned the scientific and popular press (van Heerden, 2004).

Products enriched with compounds familiar to consumers (Frewer et al, 2003) or ingredients that are in the mind of consumers for a longer time (Menrad, 2003) are more likely to result in consumer acceptance and success of such products. Consumer awareness supported probiotic product developments in the United States (US) (O'Donnell, 2004). Hilliam (1996) also positioned functional foods purchasing in Europe towards consumers with higher awareness and better knowledge of the foods. Market failure of probiotic products has also been linked to a lack of reasonable product knowledge by consumers (Prado et al, 2008). Increased consumer awareness and knowledge would therefore benefit pro- and prebiotic product development and the market penetration of such foods in SA.

The gastrointestinal microflora forms an integral and biologically important component of the body (Saarela et al, 2002; Sanders, 2003). As their health benefits are now acknowledged (Sanders, 2003) two exogenous approaches utilising bioactive food ingredients to modify the composition of the gastrointestinal microflora have been attracting attention: the administration of live health-promoting microorganisms by mouth (probiotics) and the oral intake of components that stimulate intestinal health-promoting bacterial growth (prebiotics) (Saarela et al, 1998). Strains of Lactobacillus acidophilus and bifidobacterium spe- 
cies, collectively known as $A B$ cultures, are used as probiotic microbes (Theunissen \& Witthuhn, 2004). This term has been used in SA to indicate these health-promoting microbes in yoghurts (Theunissen et al, 2005).

Based on the above, the primary objectives of this survey were to determine (i) the awareness and knowledge of pro-, prebiotics and $A B$ cultures among yoghurt buyers as mainstream probiotic product consumers in SA, along with the respondent biographic factors associated with the awareness and knowledge of pro-, prebiotics and $A B$ cultures, and (ii) the factors determining their yoghurt buying decision. In addition the survey also explored (iii) if any association existed between the respondent pro-, prebiotic and $A B$ culture awareness and (iv) the respondent interest in knowing more about pro- and prebiotics.

\section{METHOD AND MATERIALS}

\section{Instrument}

A self-administered questionnaire that comprised of 22 questions was developed. Respondents firstly indicated if they had heard of pro-, prebiotics and $A B$ cultures ( $\mathrm{N}=3$ questions). These indications were used to determine their awareness of each of the bioactive food ingredients. For the purpose of this survey awareness was regarded as "cognisance of" (Butterfield, 2003:113). Those respondents that indicated awareness of a term were further asked to describe what the term meant $(\mathrm{N}=3$ further questions). Their description was used to determine their knowledge of the bioactive food ingredient, which for the purpose of this survey was regarded as "an acquaintance with facts" (Harber \& Payton, 1979:599). Probiotics, and even prebiotics, have been defined in several ways (see Table 1). Considering these definitions the general theme emphasising "live microorganisms that beneficially influence health (or improve intestinal microbial balance)" and "food compo- nents/ingredients that stimulate/promote growth of beneficial bacteria (in the colon/large intestine)" was used to respectively accept the correct description for pro- and prebiotics. Although Lactobacillus acidophilus and bifidobacterium species are collectively known as AB cultures (Theunissen et al, 2005) it was not expected of consumers to know the microbial strains, but rather that the term is used to indicate the presence of health-promoting microbes (Theunissen et al, 2005). "Health-promoting organisms" or "live, friendly bacteria" or such word combinations were used as the correct description for AB cultures.

In addition, the food product most associated with each bioactive food ingredient ( $N=3$ questions), the health benefit of $A B$ cultures ( $N=1$ question), the information sources of pro- as well as prebiotics ( $\mathrm{N}=2$ questions), the respondent dietary supplement use $(\mathrm{N}=1$ question) and yoghurt consumption ( $\mathrm{N}=3$ questions), the factors determining their yoghurt buying decision ( $\mathrm{N}=1$ question) and if they were interested in knowing more about pro- and prebiotics ( $\mathrm{N}=1$ question) were also determined. It had been indicated that health conscious individuals may be motivated to process complex diet and health messages (Frewer et al, 2003). Health conscious individuals may therefore be the consumers aware of pro- and prebiotics. Dietary supplement use was as a result determined as supplement use had been associated with consumers with a healthier lifestyle profile (Kirk et al, 1999). The demographic information sought included details on gender, age, first language ( $\mathrm{N}=1$ question respectively) and racial/ethnic status (optional question).

An introductory comment was provided on the questionnaire cover page indicating the purpose of the survey along with clear instructions for its completion. The questions were mostly in the multiple-choice format $(\mathrm{N}=19$, with the questions related to the information sources of pro- and prebiotics and the factors determining the yoghurt buying decision allowing for

\section{TABLE 1: PUBLISHED PROBIOTIC AND PREBIOTIC DEFINITIONS}

\begin{tabular}{|c|c|c|}
\hline & Published definition & Reference \\
\hline \multirow{5}{*}{ Probiotic } & $\begin{array}{l}\text { Living microorganisms that, upon digestion in certain numbers, exert health benefits beyond inherent basic } \\
\text { nutrition. }\end{array}$ & $\begin{array}{l}\text { Guarner \& } \\
\text { Schaafsma, } 1998\end{array}$ \\
\hline & A mono or mixed culture of microorganisms which when applied to animal or man affect the host beneficially. & Sanders, 1998 \\
\hline & $\begin{array}{l}\text { A preparation of or a product containing viable, defined microorganisms in sufficient numbers, which alter the } \\
\text { microflora (by implantation or colonisation) in a compartment of the host and by that exert beneficial health } \\
\text { effects in this host. }\end{array}$ & Schrezenmeir \& de Vrese, 2001 \\
\hline & \begin{tabular}{|l|l} 
Live microorganisms which when administered in adequate amounts confer a health benefit on the host. \\
\end{tabular} & FAO/WHO, 2002 \\
\hline & \begin{tabular}{|l} 
Live bacteria indigenous to the human intestinal tract, which, when consumed in adequate numbers, benefi- \\
cially affect the health and functioning of the host's intestinal tract by modulating mucosal and systemic immu- \\
nity as well as improving the nutritional and microbial balance and are therefore considered a dietary adjuvant \\
and are added to foodstuffs for their prophylactic and health enhancing properties.
\end{tabular} & $\begin{array}{l}\text { South Africa. } \\
\text { Department of } \\
\text { Health, } 2007\end{array}$ \\
\hline \multirow{4}{*}{ Prebiotic } & $\begin{array}{l}\text { A non-digestible food ingredient that beneficially affects the host by selectively stimulating the growth, activity } \\
\text { or both of one or a limited number of bacterial species already resident in the colon that can improve the host } \\
\text { health. }\end{array}$ & $\begin{array}{l}\text { Gibson \& } \\
\text { Roberfroid, } 1995\end{array}$ \\
\hline & $\begin{array}{l}\text { A colonic food which encourages the growth of favourable intestinal bacteria (e.g. bifidobacteria and lactoba- } \\
\text { cilli). }\end{array}$ & Sanders, 1998 \\
\hline & $\begin{array}{l}\text { An indigestible food ingredient that beneficially affects the host by selectively stimulating the growth or activ- } \\
\text { ity, or both, of one bacterium or a limited number of bacteria in the colon, thus improving the host's health. }\end{array}$ & Jones, 2002 \\
\hline & $\begin{array}{l}\text { A non-digestible food component or ingredient with a degree of polimerisation between } 2 \text { to } 60 \text { which has a } \\
\text { proven beneficial effect on the host's health by selectively stimulating the growth and metabolic activities of } \\
\text { one or a limited number of beneficial, indigenous, intestinal bacteria, thus improving the host's intestinal } \\
\text { balance. }\end{array}$ & $\begin{array}{l}\text { South Africa. } \\
\text { Department of } \\
\text { Health, } 2007\end{array}$ \\
\hline
\end{tabular}

Awareness and knowledge of Pro-, Prebiotics and AB cultures among yoghurt buyers in four

Pretoria suburbs and the factors determining their yoghurt buying decision 
more than one response as answer). Supply type questions $(\mathrm{N}=3)$ to obtain descriptions for pro-, prebiotics and $A B$ cultures were also included. The questionnaire was pre-tested on yoghurt buyers $(\mathrm{N}=25)$ after obtaining approval for the survey from the Faculty Research Committee of the Cape Peninsula University of Technology. Minor questionnaire changes were made providing for face validity (Thorndike et al, 1991:126).

\section{Sample and procedure}

Since much of the innovation in the use of pro- and prebiotics has been in dairy products (Walzem, 1999), it was expected that yoghurt buyers would likely be the mainstream consumers familiar with and interested in these ingredients. The profile of functional food users has emerged as being female, educated, of a higher age and with the presence of young children in the household (Binkley, 2003; Verbecke, 2005). Saher et al (2004), however, concluded that very different consumers might emerge depending on the health claim. As it has been emphasised that the domain of functional foods is promoting health (Sanders, 1998) all yoghurt buyers were approached for participation, regardless of their health status, gender, age and the presence of children in the household.

A letter from the institution was provided to the Head Office of a food retail store chain trading in the higher living standards measure (LSM) markets in SA. The letter explained the survey and that their customers were sought after as functional foods are often more expensive than the standard counterparts, suggesting that income may influence functional food purchasing (Binkley, 2003; Frewer et al, 2003). Hilliam (1996) positioned functional foods purchasing in Europe towards higher socio-economic groups. In a survey among Irish adults those of a higher social classification were more aware of the term probiotics and also scored higher on a frequency of probiotic yogurt consumption scale than respondents in lower socioeconomic classes (Bogue et al, 2003).

A letter of consent was obtained from the food retail store Head Office to conduct the survey in four stores located respectively in the Pretoria suburbs of Montana, Gezina, Menlyn and Centurion. Authorisation was also obtained from the store managers. Through systematic sampling every third yoghurt buyer was approached for voluntary and anonymous participation, to obtain a sample size of 300 customers with approximately 75 yoghurt buyers per store. More customers were approached to allow for voluntary participation and incomplete answering of questionnaires. Three hundred and seventy six yoghurt buyers were invited across the food stores to participate of whom 311 completed the questionnaire on providing oral consent (response rate of $82,7 \%$ ). Eleven questionnaires were rejected, as they were incomplete or not answered as indicated, providing for a final sample of 300 . The survey was conducted in the latter half of 2005.

\section{Data analysis}

All question responses were coded and entered onto Microsoft@ Excel 2000 (9.0.2720) spreadsheets and imported into the STATISTICA data analysis software system, version 7.1 (Statsoft, Inc., 2005). Frequency distributions were determined for all responses and analysed to determine associations or differences between data categories utilising the Pearson chisquare test. A significant level of $p<0,05$ was used.

\section{RESULTS}

\section{Respondent demographic characteristics}

The sample was mainly females $(65,7 \%)$ with most respondents between 18 and 39 years $(66,7 \%)$ and Afrikaans speaking (83\%) (Table 2). As approximately two-thirds $(63,3 \%)$ of the sample were dietary supplements users (Table 3 ), the sample profile related to persons who were likely to engage in health-related behaviours (Kirk et al, 1999).

Respondent pro-, prebiotic and $A B$ culture awareness, knowledge, food product association and major information sources

TABLE 2: DEMOGRAPHIC CHARACTERISTICS OF RESPONDENT SAMPLE $(\mathrm{N}=300)$

\begin{tabular}{|l|c|c|}
\hline \multicolumn{1}{|c|}{ Respondent demographic characteristics } & Number & \% \\
\hline Gender & 197 & 65,7 \\
\hline Female & 103 & 34,3 \\
\hline Male & \multicolumn{2}{|c|}{} \\
\hline Age (years) & 200 & 66,7 \\
\hline $18-39$ & 92 & 30,7 \\
\hline $40-64$ & 8 & 2,7 \\
\hline$\geq 65$ & \multicolumn{3}{|c|}{} \\
\hline First language & 249 & 83,0 \\
\hline Afrikaans & 51 & 17,0 \\
\hline English & \multicolumn{3}{|c|}{} \\
\hline Racial/Ethnic status & 252 & 84,0 \\
\hline White & 9 & 3,0 \\
\hline Coloured & 37 & 12,3 \\
\hline Black & 2 & 0,7 \\
\hline Indian & \multicolumn{3}{|c|}{} \\
\hline
\end{tabular}


Only $14 \%$ of the respondents had heard of probiotics (Table 3 ) and only $10,7 \%$ provided a description of it. Only $56,3 \%$ of these respondents gave a correct description for probiotics (Table 4). The food product these respondents aware of probiotics mostly associated it with was yoghurt (83.3\%), followed by cereal products $(11,9 \%)$. One respondent associated probiotics with vegetables, one probiotics with sweets and one respondent did not know which food product to associate probiotics with. The printed media $(50 \%)$, family, friends and/or colleagues $(45,2 \%)$ and food product labels, advertising and/or brochures (35,7\%) were the major probiotic information sources of these respondents.
Only ten respondents had heard of prebiotics of whom six provided a description of it. Two of these respondents gave a correct description. The food product which these ten respondents associated with prebiotics was yoghurt (six respondents), followed by cereal products (three respondents), and lastly sweets (one respondent). Prebiotics are finding increasing application outside the dairy sector, particularly in baked goods (Walzem, 1999). The respondents aware of prebiotics indicated family, friends and/or colleagues (five respondents) and the printed media (four respondents) as their major sources of information.

Only $26,7 \%$ of the respondents had heard of $A B$ cultures (Table 3 ) and only $16,3 \%$ provided a description

TABLE 3: ASSOCIATIONS BETWEEN RESPONDENT PROBIOTIC AND AB CULTURE AWARENESS AND THEIR BIOGRAPHIC CHARACTERISTICS

\begin{tabular}{|c|c|c|c|c|c|c|c|c|c|c|c|c|}
\hline \multirow{2}{*}{\multicolumn{3}{|c|}{$\begin{array}{l}\text { Respondents and respondent bio- } \\
\text { graphic characteristics }\end{array}$}} & \multicolumn{5}{|c|}{ Respondent probiotic awareness } & \multicolumn{5}{|c|}{ Respondent $A B$ culture awareness } \\
\hline & & & \multicolumn{2}{|c|}{ Aware } & \multicolumn{2}{|c|}{ Unaware } & \multirow{2}{*}{$p$} & \multicolumn{2}{|c|}{ Aware } & \multicolumn{2}{|c|}{ Unaware } & \multirow{2}{*}{$p$} \\
\hline & $\mathrm{Na}$ & $\%$ & $\mathrm{Na}$ & $\%$ & $\mathrm{Na}$ & $\%$ & & $\mathrm{Na}$ & $\%$ & $\mathrm{Na}$ & $\%$ & \\
\hline Respondents & 300 & & 42 & 14 & 258 & 86 & & 80 & 26,7 & 220 & 73,3 & \\
\hline \multicolumn{13}{|l|}{ Gender } \\
\hline Female & 197 & 65,7 & 29 & 14,7 & 168 & 85,3 & & 55 & 27,9 & 142 & 72,1 & \\
\hline Male & 103 & 34,3 & 13 & 12,6 & 90 & 87,4 & $0,619^{b}$ & 25 & 24,3 & 78 & 75,7 & $0,498^{b}$ \\
\hline \multicolumn{13}{|l|}{ Age (years) } \\
\hline $18-39$ & 200 & 66,7 & 28 & 14,0 & 172 & 86,0 & & 54 & 27,0 & 146 & 73,0 & \\
\hline $40-64$ & 92 & 30,7 & 14 & 15,2 & 78 & 84,8 & & 23 & 25,0 & 69 & 75,0 & \\
\hline$\geq 65$ & 8 & 2,7 & 0 & 0 & 8 & 100,0 & $0,493^{b}$ & 3 & 37,5 & 5 & 62,5 & $0,733^{b}$ \\
\hline \multicolumn{13}{|c|}{ Yoghurt consumption } \\
\hline Consumers & 267 & 89 & 39 & 14,6 & 228 & 85,4 & & 75 & 28,1 & 192 & 71,9 & \\
\hline Non-consumers & 33 & 11 & 3 & 9,1 & 30 & 90,9 & $0,389^{\mathrm{b}}$ & 5 & 15,2 & 28 & 84,8 & $0,113^{b}$ \\
\hline \multicolumn{13}{|c|}{ Dietary supplement use } \\
\hline Users & 190 & 63,3 & 32 & 16,8 & 158 & 83,2 & & 50 & 26,3 & 140 & 73,7 & \\
\hline Non-users & 110 & 36,7 & 10 & 9,1 & 100 & 90,9 & $0,062^{b}$ & 30 & 27,3 & 80 & 72,7 & $0,857^{b}$ \\
\hline
\end{tabular}

a $\mathrm{N}$ - Number

${ }^{b}$ Non-significant $(p>0,05)$

TABLE 4: ASSOCIATIONS BETWEEN RESPONDENT PROBIOTIC AND AB CULTURE KNOWLEDGE AND THEIR BIOGRAPHIC CHARACTERISTICS

\begin{tabular}{|c|c|c|c|c|c|c|c|c|c|c|c|c|}
\hline \multirow{3}{*}{$\begin{array}{l}\text { Respondent } \\
\text { biographic char- } \\
\text { acteristics }\end{array}$} & \multicolumn{6}{|c|}{ Respondent probiotic knowledge $(\mathrm{N}=32)$} & \multicolumn{6}{|c|}{ Respondent $A B$ culture knowledge $(\mathrm{N}=49)$} \\
\hline & \multirow{2}{*}{$\mathrm{Na}$} & \multicolumn{2}{|c|}{ Correct } & \multicolumn{2}{|c|}{ Incorrect } & \multirow[b]{2}{*}{$\mathrm{p}$} & \multirow{2}{*}{$\mathrm{Na}$} & \multicolumn{2}{|c|}{ Correct } & \multicolumn{2}{|c|}{ Incorrect } & \multirow[b]{2}{*}{$\mathbf{p}$} \\
\hline & & $\mathrm{N}^{\mathrm{a}}$ & $\%$ & $\mathrm{Na}^{\mathrm{a}}$ & $\%$ & & & $\mathrm{Na}^{\mathrm{a}}$ & $\%$ & $\mathrm{Na}^{\mathrm{a}}$ & $\%$ & \\
\hline \multicolumn{13}{|l|}{ Gender } \\
\hline Female & 22 & 12 & 54,5 & 10 & 45,5 & & 33 & 18 & 54,5 & 15 & 45,5 & \\
\hline Male & 10 & 6 & 60,0 & 4 & 40,0 & $0,773^{c}$ & 16 & 6 & 37,5 & 10 & 62,5 & $0,263^{\mathrm{c}}$ \\
\hline \multicolumn{13}{|l|}{ Age (years) } \\
\hline $18-39$ & 21 & 11 & 52,4 & 10 & 47,6 & & 36 & 17 & 47,2 & 19 & 52,8 & \\
\hline $40-64$ & 11 & 7 & 63,6 & 4 & 36,4 & $0,821^{\mathrm{c}}$ & 13 & 7 & 53,8 & 6 & 46,2 & $0,505^{c}$ \\
\hline \multicolumn{13}{|c|}{ Yoghurt consumption: Per week ${ }^{b}$} \\
\hline $1-3$ times & 23 & 15 & 65,2 & 8 & 34,8 & & 36 & 17 & 47,2 & 19 & 52,8 & \\
\hline 4-7 times & 5 & 3 & 60,0 & 2 & 40,0 & & 11 & 6 & 54,5 & 5 & 45,5 & \\
\hline$>7$ times & 3 & 0 & 0 & 3 & 100,0 & $0,098^{c}$ & 2 & 1 & 50,0 & 1 & 50,0 & $0,944 c$ \\
\hline \multicolumn{13}{|c|}{ Yoghurt consumption: Per time ${ }^{b}$} \\
\hline$\leq 125 \mathrm{ml}$ & 12 & 8 & 66,7 & 4 & 33,3 & & 24 & 11 & 45,8 & 13 & 54,2 & \\
\hline $125-250 \mathrm{ml}$ & 13 & 7 & 53,8 & 6 & 46,2 & & 15 & 8 & 53,3 & 7 & 46,7 & \\
\hline$\geq 250 \mathrm{ml}$ & 6 & 3 & 50,0 & 3 & 50,0 & $0,733^{c}$ & 10 & 5 & 50,0 & 5 & 50,0 & $0,788^{c}$ \\
\hline \multicolumn{13}{|c|}{ Dietary supplement use } \\
\hline Users & 24 & 14 & 58,3 & 10 & 41,7 & & 34 & 17 & 50,0 & 17 & 50,0 & \\
\hline Non-users & 8 & 4 & 50,0 & 4 & 50,0 & $0,681^{c}$ & 15 & 7 & 46,7 & 8 & 53,3 & $0,617^{c}$ \\
\hline
\end{tabular}

a $\mathrm{N}$ - Number

b One respondent aware of probiotics did not consume yoghurt $(\mathrm{N}=31)$

c Non-significant $(p>0,05)$ 
of it. Only $49 \%$ of the respondents, who gave a description, were correct (Table 4). The food product the $A B$ culture aware respondents mostly associated with $A B$ cultures was yoghurt $(91,3 \%)$. Five respondents associated it with cereal products $(6,2 \%)$, while the remaining two respondents did not know which food product to associate $A B$ cultures with. The health benefits these respondents mostly associated with $A B$ cultures were healthy digestive and immune systems $(83,8 \%)$ and otherwise strong bones and teeth (10\%). Five respondents indicated not knowing a health benefit of $A B$ cultures.

\section{Associations between respondent awareness and knowledge of probiotics and $A B$ cultures and their biographic characteristics}

The associations between the respondent awareness and knowledge of the bioactive food ingredients and their biographic characteristics (i.e. their gender, age, yoghurt consumption and dietary supplement use) were only determined for probiotics and $A B$ cultures. These associations were not investigated for prebiotics as only ten respondents were aware of prebiotics of whom six described it. No significant associations ( $p>0.05$ for each) were found between the respondent awareness or knowledge of probiotics or $A B$ cultures and any of the investigated biographic characteristics.

Gender No gender difference $(p>0,05)$ was found among the respondents as $14,7 \%$ of the females and $12,6 \%$ of the males had heard of probiotics, while $85,3 \%$ and $87,4 \%$ respectively had not (Table 3 ). No gender difference $(p>0,05)$ was also found among those respondents who provided a description of probiotics either correctly $(54,5 \%$ females and $60 \%$ males) or incorrectly (45,5\% females and $40 \%$ males) (Table 4). About three times more females as well as males had not heard of $A B$ cultures $(72,1 \%$ females and $75,7 \%$ males) compared to those that had heard about it $(27,9 \%$ females and $24,3 \%$ males) $(p>0,05)$ (Table 3$)$. No gender difference $(p>0,05)$ was found among the respondents who provided a correct $(54,5 \%$ females and $37,5 \%$ males $)$ or incorrect (45,5\% females and $62,5 \%$ males) description of $A B$ cultures (Table 4).

Age Probiotics awareness was also not associated with respondent age $(p>0,05)$. In the younger age groups (18-39 years and $40-64$ years) about $85 \%$ of the respondents were unaware of probiotics $(86 \%$ and $84,8 \%$ respectively). No respondent in the age group 65 years and older had heard of probiotics (Table 3 ) or gave a description for it. In the 18 to 39 years age group a near equal percentage of the respondents provided a correct $(52,4 \%)$ and an incorrect $(47,6 \%)$ meaning. In the 40 to 64 years age group slightly more respondents provided a correct $(63,6 \%)$ compared to an incorrect $(36,4 \%)$ meaning, but the difference was not significant $(p>0,05)$ (Table 4 ). In all the age groups about $60 \%$ to $75 \%$ of the respondents were unaware of $A B$ cultures $(73 \%, 75 \%$ and $62,5 \%$ respectively) $(p>0,05)$ (Table 3$)$. About half of the respondents in the age groups 18 to 39 years and 40 to 64 years either gave a correct $(47,2 \%$ and $53,8 \%$ respectively) or an incorrect $(52,8 \%$ and $46,2 \%$ respectively) description of $A B$ cultures $(p>0,05)$. No respondent in the 65 years and older age group provided a description for $A B$ cultures (Table 4).

Yoghurt consumption Most of the respondents who consumed yoghurt and those who did not were unaware of probiotics $(85,4 \%$ and $90,9 \%$ respectively) $(p>0,05)$ (Table 3$)$. A near equal percentage of the yoghurt consumers who provided a description for probiotics provided either the correct $(58,1 \%)$ or an incorrect $(41,9 \%)$ meaning. No significant differences were also found in the weekly yoghurt consumption $(p>0,05)$ and the amount of yoghurt consumed per time $(p>0,05)$ of those who provided a description of probiotics, either correctly $(58,1 \%)$ or incorrectly $(41,9 \%)$ (Table 4$)$. However, when comparing those who consumed yoghurt one to three times a week with those who consumed it four or more times a week (combining the consumption of four to seven times and more than seven times a week), a larger percentage of those who provided an incorrect meaning consumed yoghurt four or more times a week than among those who provided the correct meaning (38,5\% and $16,7 \%$ respectively) (Table 4$)$. The difference was significant $(p<0,05)$ showing that higher yoghurt consumption did not positively influence knowing what probiotics are. Most respondents who did $(71,9 \%)$ and did not $(84,8 \%)$ consume yoghurt were unaware of $A B$ cultures $(p>0,05)$ (Table 3$)$. No differences were found in the weekly yoghurt consumption $(p>0,05)$ and the amount consumed per time $(p>0,05)$ of those who gave a description of $A B$ cultures, either correctly $(49 \%)$ or incorrectly $(51 \%)$ (Table 4).

Dietary supplement use Only $16,8 \%$ of the supplement users and $9,1 \%$ of the non-users were aware of probiotics. The majority of supplement users $(83,2 \%)$ and non-users $(90,9 \%)$ were not $(p>0,05)$ (Table 3). Knowledge of probiotics was also not associated $(p>0.05)$ with respondent dietary supplement use. A near equal percentage of users and non-users described probiotics either correctly $(58,3 \%$ and $50 \%$ respectively) or incorrectly $(41,7 \%$ and $50 \%$ respectively) (Table 4). About a quarter of those respondents using and not using dietary supplements were aware of $A B$ cultures $(26,3 \%$ and $27,3 \%$ respectively) $(p>0,05)$ (Table 3$)$, while a near equal number of respondents using and not using dietary supplements provided a correct ( $50 \%$ and $46,7 \%$ respectively) and an incorrect (50\% and $53,3 \%$ respectively) meaning for it $(p>0,05)$ (Table 4$)$.

Associations between respondent $A B$ culture and prebiotic awareness and their awareness of probiotics

Although only approximately a quarter of the respondents $(26,7 \%)$ were aware of $A B$ cultures, about half of these respondents were aware of probiotics $(43,8 \%)$ and the other half not $(56,3 \%)$. Most of the respondents unaware of probiotics $(86 \%)$ were also 
unaware of $A B$ cultures $(82,6 \%)$. The association between the awareness of $A B$ cultures and probiotics or not, was significant $(p<0,001)$ indicating that an awareness of $A B$ cultures also meant an awareness of probiotics.

Ten respondents $(3,3 \%)$ were aware of prebiotics and $42(14 \%)$ of probiotics. The ten respondents aware of prebiotics were all aware of probiotics $(100 \%)$, while the respondents unaware of prebiotics $(\mathrm{N}=290)$, were mostly unaware of probiotics $(88,9 \%)$. The association between the awareness of probiotics and prebiotics or not, was significant $(p<0,001)$ which indicated that an awareness of prebiotics also meant an awareness of probiotics.

\section{Factors determining the respondent yoghurt buy- ing decision}

The major factors determining the yoghurt buying decision indicated by the respondents who consumed yoghurt $(89 \%)$ were flavour and taste $(65,9 \%$ and $62,2 \%$ respectively). The next important factors indicated by $37 \%$ to $44 \%$ of the respondents were brand $(44,2 \%)$, fat content $(39,3 \%)$, cost $(37,4 \%)$ and health $(36,7 \%)$. The fat content was a more important factor than the sugar content as $39,3 \%$ indicated the fat content and only $19,5 \%$ the sugar content.

\section{Respondent interest in knowing more about pro- and prebiotics}

Most respondents $(80 \%)$ indicated interest in knowing more about pro- and prebiotics. This was true for the respondents aware and unaware of pro- $(92,9 \%$ and $77,7 \%$ respectively) and prebiotics (100\% and $79,3 \%$ respectively), the yoghurt consumers $(81,6 \%)$ and non-consumers $(66,7 \%)$ and the dietary supplement users $(87,4 \%)$ and non-users $(67,3 \%)$. Most females $(82,7 \%)$ and males $(74,8 \%)$ and most respondents in each of the age groups $(78,5 \%, 84,8 \%$ and $62,5 \%$ respectively) were also interested in knowing more about pro- and prebiotics.

\section{DISCUSSION}

In an exploratory study of consumer attitudes towards health-enhancing food all Irish participants $(\mathrm{N}=39)$ were unaware of probiotics (Bogue \& Sorenson, 2001). A Markinor survey conducted in 2005 in Metropolitan areas across the provinces in SA indicated a probiotics awareness of $14 \%$ (Robertson, 2005). This survey also found a low probiotics awareness among yoghurt buyers as the mainstream probiotic product consumers. Seventy percent of the respondents in an Irish survey (Bogue et al, 2003) were also not able to explain probiotics. Lack of knowledge of probiotics, and of prebiotics and $A B$ cultures, was also confirmed in this survey. The low awareness and knowledge of probiotics is not unique to consumers. Amongst Nigerian clinicians surveyed, 95,2\% were not familiar with probiotics (Anukam et al, 2006) and only $31 \%$ of physician practices in a small Canadian city had knowledge of probiotics (Edmunds, 2001).
In the Irish survey mentioned above significantly more females than males (73\% versus $57 \%$ ) were aware of probiotics (Bogue et al, 2003). In this survey, however, gender along with age, yoghurt consumption and dietary supplement use did not influence awareness or knowledge of probiotics or $A B$ cultures. Although most yoghurt buyers were oblivious of the existence of pro- and prebiotics, and even $A B$ cultures, an awareness of $A B$ cultures and an awareness of prebiotics were significantly associated with an awareness of probiotics.

The Irish survey furthermore indicated that $67 \%$ of the participants were unaware of the health benefits associated with probiotic yogurts (Bogue et al, 2003). In the exploratory Irish study the participants were also unaware of the benefits of consuming live cultures and perceived probiotic yoghurts to be equivalent to conventional yoghurts (Bogue \& Sorenson, 2001). In the 2005 International Food Information Council (IFIC) and IFIC Foundation US consumer web-based survey of US adults, $49 \%$ and $47 \%$ were respectively aware of probiotics and prebiotic fibres for maintaining a healthy digestive tract and $46 \%$ for probiotics maintaining a healthy immune system (Reinhardt, 2005). The health benefits the respondents in this survey, who were aware of $A B$ cultures, mostly associated with $A B$ cultures were maintaining healthy digestive and immune systems.

The two major factors indicated by about two-thirds of the participants in this survey to determine the yoghurt buying decision were flavour and taste. Taste plays a major role in the buying decision (Sloan, 1998). The fat content was also indicated in determining the yoghurt buying decision in this survey. The trend towards lower-fat yoghurts is well established (Hilliam, 2001) possibly because fat is the nutrient indicated as the greatest nutritional health concern by consumers (Sloan, 1998). In the Irish survey mentioned previously, a significant association $(p<0,001)$ was found between the awareness of probiotic yoghurts and purchase intent (Bogue et al, 2003).

In the 2005 IFIC and IFIC Foundation US consumer web-based survey $83 \%$ of the adult respondents were interested in learning more about the health benefits offered by functional foods (Reinhardt, 2005). In this survey most respondents also indicated interest in knowing more about pro-and prebiotics, regardless of their awareness or not of probiotics and prebiotics, or whether consuming yoghurt or dietary supplements or not, and their gender or age.

\section{CONCLUSIONS}

Despite the availability of probiotic food products and dietary supplements, publications on this topic, and food labelling legislation on pro- and prebiotics to be finalised in SA, only $14 \%$ of the South African adults interviewed in the Markinor survey were aware of probiotics (Robertson, 2005). It was consequently concluded that most South Africans were oblivious of the existence of probiotics, and more so for prebiotics, as even consumers who purchased yoghurt that 
could be considered mainstream probiotic product consumers, and who had a profile related to persons likely to engage in health-related behaviours, had limited awareness of these bioactive food ingredients. It had also been postulated that of those who have knowledge on probiotics the accuracy of the knowledge might be flawed (Reid et al, 2003) as was found in this survey. Very few yoghurt buyers could provide the correct meaning for pro- or prebiotics, or even $A B$ cultures. Witwer (1999) employs a three-phase model to track consumer acceptance of bioactive food ingredients. In the first or emerging consumer acceptance phase the majority of consumers had just become aware of the ingredient and its health benefits with some educated and proactive consumers understanding the bioactive food ingredient. Witwer (1999) indicated that most bioactive ingredients, including probiotics, were in the emerging phase as was confirmed in this survey. Despite that most yoghurt buyers were oblivious to the existence of pro- and prebiotics and even $A B$ cultures, an awareness of $A B$ cultures was associated with an awareness of probiotics, and an awareness of prebiotics with an awareness of probiotics. This indicated the existence of some educated and proactive consumers. It was disappointing to find that only about a quarter of the respondents were aware of $A B$ cultures, a term that has been used to indicate the presence of health-promoting microbes in South African yoghurts for some time. Respondent gender, age, yoghurt consumption and dietary supplement use did not impact awareness of any of the bioactive food ingredients questioned. The health benefits the respondents aware of $A B$ cultures mostly associated $A B$ cultures with were maintaining healthy digestive and immune systems, health benefits also attributed in other studies (Reinhardt, 2005).

Bhaskaran and Hardley (2002) determined that the information on the nutritional fact panel used by consumers for food purchase decisions was limited to identifying the content of fat, sugar, salt or calories, not other information unless the respondents had specific knowledge about or interest in other ingredients. This was established in this survey, as the presence of health-promoting bacteria was not indicated in determining the yoghurt buying decision. However, most respondents indicated interest in knowing more about pro- and prebiotics as was found in the 2005 IFIC and IFIC Foundation US consumer web-based survey for functional foods (Reinhardt, 2005).

\section{RECOMMENDATIONS}

Limited consumer awareness had been indicated to threaten the development of probiotic markets and increasing consumer knowledge of probiotics cited a priority (Probiotic suppliers face consumer awareness barrier, 2004). If consumers were unaware of a product, they would not seek or buy it with the exception of impulse purchases (Straub, 2004). Although low consumer awareness of probiotics might hamper such product market penetration in SA, consumer interest could be the sustaining factor. O'Donnell (2004) indicated consumer interest as half the battle in creating and successfully introducing new products.
Positive probiotic newspaper and magazine coverage contributed to increased consumer probiotic awareness in the US (O'Donnell, 2004). Witwer (1999) furthermore indicated that emerging bioactive food ingredients have the potential to move into the second or growth phase of consumer acceptance when supported by concerted educational effort. In addition, Menrad (2003) stated that limited consumer awareness and knowledge of newly developed functional ingredients bring about a strong need for specific information and communication activities to consumers. Advertising messages most effective in raising awareness or delivering a comprehensible, but reasonable message would have to be sought (Straub, 2004; Prado et al, 2008). The printed media along with family, friends and colleagues were found to be the respondents' major source of information on pro- and prebiotics. However, although the printed media is a major nutritional health information source to South Africans they question the credibility thereof (Charlton et al, 2004). This should be kept in mind when using this medium as public acceptance is influenced by the perceived credibility of the information (Bruhn, 2007). Repetition of the bioactive food ingredient communication message would furthermore also play a key role to produce consumer understanding and acceptance (Witwer, 1999; Bruhn, 2007) along with support from public health and major research organisations (Witwer, 1999).

The scope for probiotics to become an important food commodity for South African adults and children is extensive. Their best substantiated effects are alleviation of lactose intolerance and diarrhoea (Stanton et al, 2001). Lactase deficiency is common in the South African black population reaching an incidence of $78 \%$ (Segal et al, 1983), while the incidence of diarrhoea in children six to 23 months of age is $23 \%$ and for children under the age of five years 13\% (South Africa, Department of Health, 1998). SA further has the fifth highest prevalence of Human Immunodeficiency Virus (HIV) in the world with $21.5 \%$ of the population infected and women facing the greater infection risk (AIDS Foundation South Africa, 2005). The potential of probiotics to reduce bacterial vaginosis (Reid et al, 2003) is particularly important as this condition significantly increases the risk of HIV (Myer et al, 2005). Dyslipidaemia, hypertension and neoplasms also significantly contribute to the burden of diseases in SA (Steyn et al, 2006). The potential use of probiotics in these chronic health concerns (Saarela et al, 2002) holds further promise to enhance public health in SA.

A considerable number of South Africans already consume yoghurt and fermented milk products. This means that no change in dietary behaviour is necessary in a pro- and possibly prebiotics functional dairy food strategy for health promotion and disease prevention in SA. The respondents indicated flavour and taste as the major factors determining the yoghurt buying decision. Yoghurt, being a food that tastes good and is enjoyable (Stanton et al, 2001), can thus meet the sensory properties consumers also expect for functional foods (Frewer et al, 2003). In the US a 
seal helps consumers identify yogurt meeting the minimum standards for live, active cultures (Sanders, 2003). In SA there is no uniformity to the label statements or logos alerting consumers to the presence of $A B$ cultures. This might have hampered delivering the $A B$ culture message over the years. Uniform indication to the presence of probiotics should therefore be considered for South African product labels.

\section{REFERENCES}

NIELSEN, AC. 2005. A global ACNielsen online survey on consumer attitudes towards functional foods and organics. Available on line. URL: http:// w w w 2. a c n i e Is e n. com/re port s/ documents/2005_cc_functional_organics.pdf. Accessed 31 July 2006.

AIDS FOUNDATION SOUTH AFRICA. 2005. HIV/ AIDS in South Africa. Available on line. URL: http:// www.aids.org.za/hiv.htm. Accessed 17 August 2006. ANUKAM, KC, OSAZUWA, EO \& REID, G. 2006. Knowledge of probiotics by Nigerian clinicians. International Journal of Probiotics and Prebiotics 1(1):5762.

BHASKARAN, S \& HARDLEY, F. 2002. Buyer beliefs, attitudes and behaviour: foods with therapeutic claims. Journal of Consumer Marketing 19(7):591606.

BINKLEY, J. 2003. Determinants of functional food consumption. Workshop on the use of scanner data in policy analysis. Economic Research Service, USDA and the Farm Foundation, Washington, DC. June, 9. Available on line. URL: http:// www.farmfoundation.org/projects/documents/ ScannerDataWorkshopSummaries2_000.pdf. Accessed 31 July 2006.

BOGUE, J, COLEMAN, T \& SORENSON, D. 2003. Health-enhancing foods: Relationships between attitudes, beliefs and dietary behaviour. Agribusiness Discussion Paper No 39. Department of Food Business and Development. University College, Cork Ireland.

BOGUE, J \& SORENSON, D. 2001. An exploratory study of consumers' attitudes towards healthenhancing foods. Agribusiness Discussion Paper No 36. Department of Food Business and Development. University College, Cork Ireland.

BRUHN, CM. 2007. Enhancing consumer acceptance of new processing technologies. Innovative Food Science and Emerging Technologies 8:555-558.

BUTTERFIELD, J. (ed). 2003. Collins English Dictionary Complete \& Unabridged. $6^{\text {th }}$ ed. Glasgow. Harper Collins.

CHARLTON, KE, BREWITT, P \& BOURNE, LT. 2004. Sources and credibility of nutrition information among black urban South African woman, with a focus on messages related to obesity. Public Health Nutrition 7(6):801-811.

EDMUNDS, L. 2001. The underuse of probiotics by family physicians. Canadian Medical Association Journal 164:1577.

FOOD AND AGRICULTURAL ORGANISATION/ WORLD HEALTH ORGANISAION (FAOMHO). 2002. Guidelines for the evaluation of probiotics in food. Available on line. URL: http://www.who.int/ foodsafety/fs_management/en/ probiotics_guidelines.pdf. Accessed 17 August 2006. FREWER, L, SCHOLDERER, J \& LAMBERT, N. 2003. Consumer acceptance of functional foods: issues for the future. British Food Journal 105(10):714731.

GIBSON, GR \& ROBERFROID, MB. 1995. Dietary modulation of the human colonic microbiota: introducing the concept of prebiotics. Journal of Nutrition 125 (6):1401-1412.

GUARNER, F \& SCHAAFSMA, GJ. 1998. Probiotics. International Journal of Food Microbiology 39:237238.

HARBER, K \& PAYTON, G. 1979. Heinemann English Dictionary. London. Heinemann Educational Books.

HILLIAM, M. 1996. Functional foods: the Western consumer viewpoint. Nutrition Reviews 54(11):S189S195.

HILLIAM, M. 2001. Chilled desserts. The World of Food Ingredients Feb/March:16-18.

JONES, PJ. 2002. Clinical nutrition: 7. Functional foods - more than just nutrition. Canadian Medical Association Journal 166(12): 1555-1563.

KIRK, SFL, CADE, JE, BARRETT, JH \& CONNER, M. 1999. Diet and lifestyle characteristics associated with dietary supplement use in women. Public Health Nutrition 2(1):69-73.

KLAENHAMMER, TR, CONNOLLY, JF, FITZGERALD, RJ, STANTON, C \& ROSS, RP. 1998. Editorial. International Dairy Journal 8:v.

MARK-HERBERT, C. 2004. Innovation of a new product category - functional foods. Technovation 24:713719.

MENRAD, K. 2003. Market and marketing of functional food in Europe. Journal of Food Engineering 56:181-188.

MYER, L, KUHN, L, STEIN, ZA, WRIGHT, TC \& DENNY, L. 2005. Intravaginal practices, bacterial vaginosis and women's susceptibility to HIV infection: epidemiological evidence and biological mechanisms. Lancet Infectious Diseases 5:786-794.

O'DONNELL, J. 2004. Probiotics gaining more importance in evolution of dairy industry. California Dairy Dispatch 13(4):3.

PRADO, FC, PARADA, JL, PANDEY, A \& SOCCOL, CR. 2008. Trends in non-dairy probiotic beverages. Food Research International 41:111-123.

PROBIOTIC SUPPLIERS FACE CONSUMER AWARENESS BARRIER. 2004. Food Review 31 (5):17.

REID, G, JASS, J, SEBULSKY, MT \& MCCORMICK, JK. 2003. Potential uses of probiotics in clinical practice. Clinical Microbiology Reviews 16(4):658-672.

REINHARDT, W. 2005. US consumer attitudes and communicating the benefits of foods for health. The Sixth Joint CSL/JIFSAN International Symposium on Food Safety and Nutrition: Bioactive Food Components, University of Maryland. June, 28-30. Available on line. URL: http://www.jifsan.umd.edu/cs|2005presentations.htm. Accessed 11 May 2006.

ROBERTSON, H-L. 2005. What do South Africans know about probiotics? Results of a Markinor survey Symposium. Prebiotics and probiotics: Nature's friendly bacteria an old idea with new marketing pos- 
sibilities. SAAFoST Northern Branch. Volkswagen Conference Center, Midrand. 2 November.

SAARELA, M, LÄHTEENMÄKI, L, CRITTENDEN, R, SALMINEN, S \& MATTILA-SANDHOLM, T. 2002. Gut bacteria and health foods - the European perspective. International Journal of Food Microbiology 78:99117.

SAHER, M, ARVOLA, A, LINDEMAN, M \& LÄHTEENMÄKI, L. 2004. Impressions of functional food consumers. Appetite 42:79-89.

SANDERS, ME. 1998. Overview of functional foods: Emphasis on probiotic bacteria. International Dairy Journal 8:341-347.

SANDERS, ME. 2003. Probiotics: Considerations for human health. Nutrition Reviews 61(3):91- 99.

SCHREZENMEIR, J \& DE VRESE, M. 2001. Probiotics, prebiotics, and synbiotics - approaching a definition. American Journal of Clinical Nutrition 73:361S$364 S$.

SEGAL, I, GAGJEE, PP, ESSOP, AR \& NOORMOHAMED, AM. 1983. Lactase deficiency in the South African black population. American Journal of Clinical Nutrition 38(6):901-905.

SLOAN, AE. 1998. Food industry forecast: Consumer trends to 2020 and beyond. Food Technology 52 (1):37-44

SOUTH AFRICA, DEPARTMENT OF HEALTH. 1998. South Africa Demographic and Health Survey. Chapter 7. Maternal and child health. Available on line. URL: http://www.doh.gov.za/facts/1998/sadhs98/ chapter7.pdf. Accessed 17 August 2006.

SOUTH AFRICA, DEPARTMENT OF HEALTH. 2007. Foodstuffs, Cosmetics and Disinfectants Act, No. 54 of 1972. Regulations Relating to Labelling and Advertising of Foodstuffs. Government Gazette, No. 30075, Regulation No. 642, 20 July 2007.
STANTON, C, GARDINER, G, MEEHAN, $H$, COLLINS, K, FITZGERALD, G, LYNCH, PB \& ROSS, RP. 2001. Market potential for probiotics. American Journal of Clinical Nutrition 73(Suppl):476S-483S.

STEYN, K, FOURIE, J \& TEMPLE, N. (eds.). 2006. Chronic diseases of lifestyle in South Africa: 1995 2005. Technical Report. Cape Town: South African Medical Research Council. Available on line. URL: http://www.mrc.ac.za/chronic/cdl1995-2005.pdf. Accessed 17 August 2006.

STRAUB, AM. 2004. Marketing functional foods. The World of Food Ingredients Dec:44, 46 \& 48.

THEUNISSEN, J \& WITTHUHN, C. 2004. Probiotic content: truth or fiction? Food Review 31(5):15, 17 THEUNISSEN, J, BRITZ, TJ, TORRIANI, S \& WITTHUHN, RC. 2005. Identification of probiotic microorganisms in South African products using PCR-based DGGE analysis. International Journal of Food Microbiology 98:11-21.

THORNDIKE, RM, CUNNINGHAM, GK, THORNDIKE, RL, \& HAGEN, EP. 1991. Measurement and evaluation in psychology and education. $5^{\text {th }}$ ed. New York. MacMillan.

VAN HEERDEN, I. 2004. Manufacturers react to claims regarding probiotics. InsideOut 1(1):3-16.

VERBEKE, W. 2005. Consumer acceptance of functional foods: socio-demographic, cognitive and attitudinal determinants. Food Quality and Preference 16:45-47.

WALZEM, RL. 1999. Health enhancing properties of whey proteins and whey fractions. Applications Monograph Nutritional and Beverage, U.S. Dairy Export Council. Available on line. URL: http://www./ whey2health.com/Whey-Proteins-Health-enhancingeffects.pdf. Accessed 21 August 2006. 